\title{
Beyond denial and exclusion: The history of relations between Christians and Muslims in the Cape Colony during the 17th-18th centuries with lessons for a post-colonial theology of religions
}

\begin{tabular}{|c|c|}
\hline \multicolumn{2}{|l|}{$\begin{array}{l}\text { Author: } \\
\text { Jaco Beyers }{ }^{1}\end{array}$} \\
\hline \multicolumn{2}{|c|}{$\begin{array}{l}\text { Affiliation: } \\
{ }^{1} \text { Department of Science of } \\
\text { Religion and Missiology, } \\
\text { University of Pretoria, South } \\
\text { Africa }\end{array}$} \\
\hline \multicolumn{2}{|c|}{$\begin{array}{l}\text { Corresponding author and } \\
\text { email: } \\
\text { Jaco Beyers } \\
\text { jaco.beyers@up.ac.za }\end{array}$} \\
\hline \multicolumn{2}{|c|}{$\begin{array}{l}\text { Dates: } \\
\text { Received: } 14 \text { July } 2015 \\
\text { Accepted: } 21 \text { Nov. } 2015 \\
\text { Published: } 08 \text { Apr. } 2016\end{array}$} \\
\hline \multicolumn{2}{|c|}{$\begin{array}{l}\text { How to cite this article: } \\
\text { Beyers, J., 2016, 'Beyond } \\
\text { denial and exclusion: The } \\
\text { history of relations between } \\
\text { Christians and Muslims in the } \\
\text { Cape Colony during the } \\
\text { 17th-18th centuries with } \\
\text { lessons for a post-colonial } \\
\text { theology of religions', HTS } \\
\text { Teologiese Studies/ } \\
\text { Theological Studies 72(1), } \\
\text { a3117. http://dx.doi. } \\
\text { org/10.4102/hts.v72i1.3117 }\end{array}$} \\
\hline \multicolumn{2}{|c|}{$\begin{array}{l}\text { Copyright: } \\
\text { (C) 2016. The Authors. } \\
\text { Licensee: AOSIS. This wC } \\
\text { is licensed under the } \\
\text { Creative Commons } \\
\text { Attribution License. }\end{array}$} \\
\hline \multicolumn{2}{|l|}{ Read online: } \\
\hline 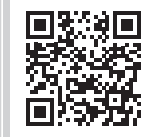 & $\begin{array}{l}\text { Scan this QR } \\
\text { code with your } \\
\text { smart phone or } \\
\text { mobile device } \\
\text { to read online. }\end{array}$ \\
\hline
\end{tabular}

Learning from the past prepares one for being able to cope with the future. History is made up of strings of relationships. This article follows a historical line from colonialism, through apartheid to post-colonialism in order to illustrate inter-religious relations in South-Africa and how each context determines these relations. Social cohesion is enhanced by a post-colonial theology of religions based on the current context. By describing the relationship between Christians and Muslims during the 17th-18th centuries in the Cape Colony, lessons can be deduced to guide inter-religious relations in a post-colonial era in South Africa. One of the most prominent Muslim leaders during the 17th century in the Cape Colony was Sheik Yusuf al-Makassari. His influence determined the future face of Islam in the Cape Colony and here, during the 18th century, ethics started playing a crucial role in determining the relationship between Christians and Muslims. The ethical guidance of the Imams formed the Muslim communities whilst ethical decline was apparent amongst the Christian colonists during the same period. The place of ethics as determinative of future inter-religious dialogue is emphasised. Denial and exclusion characterised relationships between Christians and Muslims. According to a post-colonial understanding of inter-religious contact the equality and dignity of non-Christian religions are to be acknowledged. In the postcolonial and postapartheid struggle for equality, also of religions, prof Graham Duncan, to whom this article is dedicated, contributed to the process of acknowledging the plurality of the religious reality in South Africa.

\section{Introduction}

Christianity and Islam are the two religions with the largest following in the world. ${ }^{1}$ It is, therefore, inevitable for their adherents to be in contact with one another. This engagement between Islam and Christianity has been taking place over centuries in different parts of the world. Since the rise of Islam during the 7th century CE sporadic and dramatic encounters between Christianity and Islam occurred. Contact between Christians and Muslims in South Africa only started as recently as the 17 th century.

Since the early 15th century CE Europeans (read Christians) travelled southwards along the western coastline of Africa. During the same period a parallel process was taking place on the eastern coastline of Africa. Muslim traders travelling southwards along the coast gradually made their way to the southern point of Africa. These seafarers, Christians as well as Muslims, had sporadic contact. These meetings were in general amicable but at times were also violent. The anecdotal account of Vasco da Gama making use of the knowledge of the Muslim sailor Ahmad ibn Majid (1421-1500)² to navigate around the southern point of Africa to establish a trade route to India, illustrates the amicable relationship between Christians and Muslims.

Once the southern tip of Africa was formally colonised by the Dutch in 1652, contact between Christians and Muslims in South Africa took a turn for the worse. The first Muslim to arrive at the Cape Colony was Ibrahim van Batavia, a slave from Indonesian origin brought in by the Dutch East India Company (DEIC) at the end of the 17th century (Shell 2000:327). Apparently the Dutch colonisers applied a policy that no other religion was to be tolerated in Dutch colonies. This law \footnotetext{
1.0f course there are many different forms of Christianity and Islam making it impossible to talk of two monolithic blocks of religion existing in the world.
}

2.The Ottoman historian Qutb al-Din is the first to identify the feats of Ahmad ibn Mājid. 
of 1642 was confirmed by the local Cape governor-general Johan Maetsuyker from the DEIC on 23 August 1675 (Cilliers 2006:107). No Roman Catholic or Lutheran services were permitted in public. Only in 1778 were the Lutherans permitted public worship. Compare the account David Chidester (1996:70) gives of the status of other religions in the Cape Colony. The administration of the Cape Colony must be seen in the light that its administrators considered it just another Dutch colony.

This policy on religious tolerance was influenced by the fact that the Netherlands just came out of the Eighty Years' War with Spain. The Peace of Münster in 1648 granted The Dutch not only self-governance but also religious freedom from the Roman Catholic Spaniards. The principle of cuius regio, illius religio (each region determines which religion is tolerated) became the principle by which the Dutch also governed their colonies. As the Dutch saw themselves as the dominant culture in their colonies, the religion of the coloniser prevailed and no other religion was permitted (Du Plessis 1965:21,33). The DEIC was subject to government regulations stipulating the treatment of other religions in Dutch colonies. The Second Charter of the Netherlands Government of 1622 required the DEIC to promote and protect public religion, implying the Protestant faith as expressed by the Dutch Reformed Church. Hence, Christianity became the dominant religion in the Cape Colony, and no other religion was permitted to be practiced in public. However, adherents of other religions could still continue, in private, to practice their religion.

The Cape Colony quickly became a convenient place for exiling political enemies of the DEIC (Shell 2000:327). The first such political prisoners to arrive at the Cape in 1682 consisted of political and military leaders of unruly Indonesian tribes. As the DEIC started importing labourers from other Dutch colonies, people from different cultural and religious background ended up in the Cape Colony. This 'first immigration' identified by Shell (2000:327) brought many Muslims from Indonesia to the shores of South Africa. These Muslims in the Cape Colony came from diverse cultural backgrounds (Cilliers 2006:106). In this heterogeneous context, the imams played an important role in society, and the Muslim leaders quickly made their presence felt. Thus, interaction between the two religions (Christianity and Islam) became inevitable.

It is an easy mistake to assume that the two religions under discussion are two autonomous monolithic blocks meeting one another head on. The fact of the matter is, however, that within each of these two world religions an exponential diversity exists, which is contextually determined. Cultural and social influences determine the interaction between them. This is evident from the relationship between Christians and Muslims in the Cape Colony during the 17th century. The reason why the Muslim community started in the Cape Colony is that slavery brought them to the Cape. Social interaction between adherents of the different religions caused stereotypes to be constructed. Many of the objections and accusations brought against the other still determine the way in which Christians and Muslims view one another today. South Africa is no longer a colony, but is currently a democratic republic with a Constitution guaranteeing religious freedom. However, the context remains multi-cultural and multi-religious. How do religions now, in a postcolonial era, meet one another? What should the relationship between Muslim and Christian inhabitants of South Africa be like today? From the relationship in the past, a new postcolonial model for future relations of religions can be constructed.

\section{Colonial life}

Much of the 17th century saw Europe entangled in war. The Eighty Years' War between Spain and the Netherlands overlapped with the Thirty Years' War. It was not only Europe that was involved in these wars, but also all of the colonies participated. This saw many of the Dutch colonies in Africa and the East involved in the struggle. The colonial wars were mainly fought by alliances of the Dutch government. In this regard the Dutch West India and Dutch East India Companies must be mentioned. These companies under charter of the Dutch Republic had almost sovereign powers over the colonies that they governed. They could declare war and enter treaties on behalf of the Republic in local colonies. As companies with business interests they had permission to explore and exploit the colonies for wealth. They, however, remained subject and loyal to the Republic, serving the goals and interests of the Dutch people.

The southern tip of Africa was relatively quiet during this period - as no local opposition necessitated war. ${ }^{3}$ This made the Cape Colony a good place to send political enemies and prisoners of war of the colonies. Further, the need for labourers in the Cape Colony made it plausible to import slaves to the Cape Colony. The local Khoi population proved to be 'too lazy' and possess a 'lack of industry' to be employed productively (Chidester 1996:45).

Labour in the Dutch colonies was performed by slaves. Six years after Jan van Riebeeck established a trading post in 1652 at the Cape Colony the first consignment of slaves followed. A DEIC regulation prevented colonists from enslaving indigenous people in the place of settlement (Villa-Vicencio \& Grassow 2005). Soon slaves from West Africa, Mozambique, Madagascar and further east (Java, Bali, Indonesia, China and India) followed. Slaves in the Cape Colony consisted of a heterogeneous group of people viewing one another with suspicion resulting from unfamiliarity with the culture of the other. The majority of the slaves and political prisoners from the East were Muslim. A distinctive class difference amongst slaves created inequality. Hand labourers had a different status to literate slaves. Under the DEIC regulations slaves guilty of criminal activities were severely punished, and there was a high incidence of runaway slaves. The small community of runaway slaves, that gathered around the compound of Sheik

3.Chidester (1996:43) however, mentions the Hottentot resistance (1659, 1673-1677) at the Cape Colony as some form of war. 
Yusuf at Zandvliet, is just one example (Villa-Vicencio \& Grassow 2005).

Colonies were not only seen as an extension of the property of the Dutch people but, more preferably, as economic assets. The DEIC as a business enterprise governed the colonies on behalf of the people of the Netherlands. Colonies were seen as 'branches' of the business of the trading company known as the Dutch East Indian Company.

Concerning social interaction it needs to be kept in mind that society as such had a simple hierarchical structure: rulers were at the top and the rest of the population were labourers. At the very bottom of society were the slaves. Slavery remained part of the European social structure for much of the 17th century, in which slaves were considered to belong to a lower stratum than the labouring Dutch (free) folk. In this system, not only social but also religious segregation prevailed.

\section{Status of slaves}

Muslim slaves at the Cape Colony were prevented from practising their faith in public (Chidester 1996:70). This was prohibited by Dutch colonial law until 1795 (Cilliers 2006:107). The Muslims were, however, permitted to practise their faith at home. The practice of home-bound religion consolidated the strength of families as well as the Muslim community. Religion played the role of consoling those who experienced the hardship of slavery. Being slaves was not the only thing they had in common. They now shared a common religion: being Muslim.

Cilliers (2006:107) indicates that through inter-marriage the Muslim slaves at the Cape Colony grew even stronger as a united community. Islam became the new 'home' for the dislocated slaves, exiles and refugees. In Islam many unprivileged members of society found a new identity. Marriages amongst Muslims were not accepted by the Cape authorities as official until 1823 (Cilliers 2006:107). The reason concerned the status of children born in slavery, as a child born from slave parents was also considered a slave and could, thus, also be sold separately from its parents just as a male and female slave could be sold separately although they considered themselves to be married. Only Christian marriages were considered legal in the Cape Colony; with baptism being considered the prerequisite for Christian marriages (Cilliers 2006:107).

Even when a slave was baptised, their assimilation into the Christian community was almost impossible. Slaves who were Christians still remained slaves. This leads Cilliers (2006:107) to deduce that Christianity contributed to the growth of Islam in southern Africa. Many Muslims decided rather to remain Muslim instead of converting to Christianity in the hope of becoming free.

In 1770 the DEIC instructed colonists (Article 9 of the Statutes of India) to teach Christian doctrine to their slaves and permit those who wished so to be baptised (Cilliers 2006:108).
This new tendency was based on an interpretation of the Synod of Dort (1618) that all Christian slaves should be set free (Villa-Vicencio \& Grassow 2005). By 1774 the DEIC declared that Christian slaves were not to be sold. They were to be set free on the death or emigration of their owner. Slaves were also now allowed to negotiate their freedom by buying it from their owners (Cilliers 2006:108). This led colonists to protect their assets by not baptising their slaves. A nonChristian slave was considered a good slave (Cilliers 2006:108). Many colonists advised their slaves to become Muslim. This was based on Islam's prohibition of alcohol consumption. Muslim slaves were, therefore, considered reliable (Villa-Vicencio \& Grassow 2005). This injustice again re-enforced the growth of Islam in the Cape. The results were that at the end of the 18th century the salve community in the Cape was mainly Muslim and the slave owners were Christian (Villa-Vicencio \& Grassow 2005), thus, entrenching the superiority with which Christians viewed themselves over Muslims.

\section{A brief history of the relationship between Christians and Muslims at the Cape}

Mention has already been made of the coming of the first Muslim to the Cape Colony. Free Muslims who decided to move to the Cape out of their own accord, had pity on fellow Muslims who were brought to the Cape Colony as slaves or political prisoners (Cilliers 2006:106). Contact between free and captive Muslims was forbidden by Dutch colonial law (Cilliers 2006:106). The political captives were held in high regard by the Cape free Muslims who looked upon the exiled political leaders for spiritual guidance. To illustrate the relationship between Christians and Muslims two examples will be presented: Sheik Yusuf, who was one of the earliest Muslim leaders at the Cape Colony, and Jan Svilt.

\section{Sheik Yusuf}

Sheik Yusuf was born in 1626 in the town of Goa on the island of Celebes, today known as Sulawesi, Indonesia (Ligtvoet 1880:90). Sheik Yusuf's father is identified as Galarrang Moncongloe and his mother as Aminah binti Damapang Ko'mara. She descended from a noble family from the Tallo kingdom. Sultan Ala'uddin, a family member of Sheik Yusuf's father, was apparently the first king on Celebes to convert to Islam. He declared Islam to be the state religion of his kingdom in 1603.

Popular sources indicate that Sheik Yusuf was born from Makassarese nobility. As a young man his father encouraged him to study the Qur'ān and basic Muslim teachings. Sheik Yusuf spent several years travelling in the near East and studying Arabic and religious sciences in Mecca (Cummings 2010:6).

At this stage much of Indonesia was a Dutch colony. Sheik Yusuf became one of the local leaders who organised the 
uprising against the colonial powers in Java. He joined Sultan Ageng of Banten in his struggle against the Dutch colonisers' attempts to conquer the Sultans of Indonesia. Dangor (1982:23) indicates that Sheik Yusuf was at the head of the auxiliary troops of the sultan, which is an indication of his active participation in armed opposition. During the campaign of 1683, Sheik Yusuf was captured and deported to Ceylon. From there he was deported in 1692, with many other Indonesian Muslims, to the Cape Colony on board the ship De Voetboog. In order to prevent Sheik Yusuf from influencing the existing Muslim community in the Cape Colony, he was settled on a remote farm called Zandvliet, at the mouth of the Eerste River some distance from Cape Town. This farm belonged to the reverend Petrus Kalden of the Dutch Reformed Church (Shell 2000:328). Sheik Yusuf and his entourage enjoyed relative freedom as long as they did not stray from Zandvliet. The colony at Zandvliet quickly became a growing Muslim community attracting many runaway and freed slaves and even Muslims eager to learn the intricacies of Islamic thought.

Somehow Sheik Yusuf's teachings spread amongst the slave community in the Cape Colony; probably by word of mouth as there was no possibility of him publishing his ideas.

The continuous appeal by the king of Goa to have Sheik Yusuf released came to no avail. In 1698 the Battavian Council issued a final refusal for his release. In 1699 Sheik Yusuf died at Zandvliet at the age of 70 . He was buried on top of a hill which became known as Macassar, named after his home town. In 1705 his remains were returned to Macassar (today known as Ujung Padang) in Indonesia. The 'kramat' at Macassar near Cape Town serves as a remembrance to the place where Sheik Yusuf lived and died during his exile and today continues to be a popular place of pilgrimage.

It is safe to assume that Sheik Yusuf, whilst in Indonesia, was regarded as a scholar in Islam, who spoke out against slavery, tyranny and oppression. Sheik Yusuf associated with the king's court and might have acted as an advisor to the king. Sheik Yusuf can be regarded as a political leader or political activist, as well as a spiritual guide to his followers.

Adrianus van Selms (1968:893) indicates that the writings by Sheik Yusuf provide an important contribution to understanding the early development of languages, especially Afrikaans, in the Cape Colony. The first Afrikaans written in the Cape Colony was written in Arabic letters. The importance of the influence of Sheik Yusuf on the Muslim community in the Cape Colony is speculated by Van Selms (1968:893) who identifies the religious influence of Sheik Yusuf as having been of the utmost importance. His presence was not a political, economic or social factor, but the religious minded Muslim community was influenced by his teachings. Van Selms (1968:893) states that Sheik Yusuf influenced the Muslim community as a mystic. Seeking the presence of God amidst worldly conditions characterised Sheik Yusuf's teaching.

\section{The diary of Jan Svilt}

The relationship between Muslims and Christians in the Cape Colony during the 18th century is vividly depicted by an inscription in the diary of Jan Svilt, the DEIC bookkeeper on the Dutch ship de Geertruijd. Svilt writes about an incident (Agnos 1978) where a certain imam stood outside the company brothel in Cape Town and whilst looking at the sailors waiting their turn in the queue commented aloud: 'You Dutch Christians preach to us of your superior religion. The Calvinists are, to hear them, the salt of the earth with God-given morals. Look at how you really are'. This accusation at Christian morals came probably from a freed convict rather than a political exile (Shell 2000:330). It illustrates the Muslim view of Christians during this period in the Cape Colony. Although Svilt felt some shame at the accusation (Shell 2000:330) he could not deny it.

This 'immorality' of the Christians is confirmed when reading the concern Commissioner Van den Broeck had in 1670. After investigating the matter Van den Broeck concluded that the number of canteens in the Cape Colony was in excess in relation to the size of the community (Du Plessis 1965:37). This situation contributed to the 'low ebb of private morality' of the colonists (Du Plessis 1965:37), confirming the accusation of the imam made against the so-called Christians. It is clear that right from the onset the colony at the Cape was not characterised by pious Christian zeal. Van Riebeeck himself indicated that many of the colonists did not attend the prescribed daily prayer meetings and attended very little to their religion. As punishment for being absent from prayer meetings Van Riebeeck further announced that the transgressor would ironically forfeit six days of wine rations! (Spilhaus 1949:46-47).

This depiction of Christians in the Cape Colony should, however, not be considered to be the only way in which Christians acted during this period. The mere presence and dominance of religion and church leaders in social matters in the Cape Colony provides a bigger picture of devoutness, piety and seriousness with religion. The fact that Van Riebeeck introduced daily communal prayer for colonists is already an indication of a serious effort at religious devotion.

As opposed to the immorality of some of the Christian colonisers, the Muslim community seem to have lived by a different set of standards. The imams played an increasing role as moral leaders to the local Muslim community although they were still viewed by the Dutch colonisers as convicts or of lesser human significance, resulting from their being nonChristian. Sheik Yusuf did exercise some influence on the local Muslim community, which determined their moral behaviour.

\section{Sheik Yusuf on mysticism and piety}

Although he was not the first Muslim to set foot on the southern tip of Africa, Sheik Yusuf indeed played a formative 
role in the establishment of the Muslim community in the Cape Colony (Dangor 1981:59).

It is safe to assume that Sheik Yusuf, whilst in Indonesia, was regarded as a scholar in Islam speaking out against slavery, tyranny and oppression. His words as recorded in his writings must be interpreted as spiritual encouragement to Muslims. He must have had a sizeable audience and a large number of followers in order to become a threat to the Dutch colonisers of Indonesia. To limit his influence Sheik Yusuf was captured and sent to the Cape Colony.

In one particular section (Yusuf 1990:15) of the document known as Zubdat al-Asrār, written by Sheik Yusuf, he indicates the way in which non-Muslims are to be treated. 'Honour the guest, even if he is a disbeliever ... He who believes in Allāh and His Messenger must honour his neighbour' (p. 15). Further on Sheik Yusuf states: 'the essential feature of good conduct with all creation is to bring comfort to them and to be cordial with them and not to be estranged from them' (p. 17). Based on this prescription how non-Muslims are to be treated, one can assume that this determined the relationship between Muslims and Christians prescribed by Sheik Yusuf to his audience in the Cape Colony.

There is, however, no clear indication from the text that Sheik Yusuf wrote these words with Christians in mind. It most probably referred to relations between Muslims and nonMuslims in Indonesia. It was highly probable that it also applied to the way in which Sheik Yusuf encouraged his Muslim audience about how to treat Christians in the Cape Colony. Dangor admits ${ }^{4}$ that Sheik Yusuf, according to tradition, was on very good terms with the governors of the Cape Colony, especially Simon van der Stel (governor 1679-1691) and Willem Adrian van der Stel (governor 1699-1707), which reflects the 'honour' and 'good conduct' that Sheik Yusuf prescribed.

The relationship between Christians and Muslims at the Cape was determined by unequal footing from the beginning. The relationship was that of conqueror-defeated, ownerslave, coloniser-colonised, majority-minority. It was not only these categories that determined the relationship but also the differences in moral behaviour. To this Cilliers $(2006: 109,111)$ attests by indicating that not much of the Gospel was visible in the lives of the colonists in the Cape.

A description of the relationship between Muslims and Christians during the 17th-18th centuries in the Cape Colony does have significance, as a precursor, about what the future relationship between these two religions could look like in the post-colonial era.

\section{Christian treatment of non-Christians in the Cape Colony}

From the first encounter between Christians and nonChristians in the Cape Colony, all non-Christian religions

4.Dangor, during an interview with the author, referred to this relationship between Yusuf and the governor. were considered to be inferior (Chidester 1996:41). During the 17th century it was assumed in Europe that Islam was, besides Christianity, Judaism and the Pagan religions, one of the world religions (Chidester 1996:33). Christianity, as institutionalised in the Dutch Reformed Church, was the sole established religion in the Cape Colony (Chidester 1996:70). It has already been mentioned how other religions and even certain Christian denominations were eschewed in the Cape Colony during the 17 th and 18th centuries. However, religious diversity was evident in the Cape (Jews, Hindus, Buddhists, Methodists, Roman Catholics, Lutherans, and followers of the Hottentot religion were all present) but these were 'inhibited or outlawed by colonial policy' (Chidester 1996:70).

The way in which the Christian colonisers viewed other religions changed over time. The apparent conviction was the denial of religion (Chidester 1996:11), especially when it came to the local Khoi people (Chidester 1996:35), as it was merely accepted that local people did not possess any religion at all. This was the way in which (Christian) Dutch colonists treated all local communities in all its colonies. The denial of the presence of God or any religion amongst the indigenous people of southern Africa led to the conclusion that they were on all accounts less than human (Chidester 1996:36) and not worthy of possessing the land they resided on (Chidester 1996:38). This functioned as an argument for the Dutch about why they may take hold of the land of the people whom they colonised.

Denial gradually changed to a policy of exclusion. Christianity was the only permitted official religion acknowledged in the Cape Colony. The recognition of the presence of God and religion amongst the Muslims surely made the Dutch colonists at least see the Muslims as a level higher than those without any religion. This, however, did not prevent the colonists from denying and excluding Muslims from the ruling social structure. Only later, during the 19th century, was Islam recognised by British missionaries to South Africa as a religion deserving of 'sensitive study' (Chidester 1996:132).

The characteristics of the relationship between Christianity and Islam progressed from denial to exclusion to 'sensitive study'. This relationship during the colonial period was, however, determined solely from the perspective of Christians. A new era in inter-religious relationship dawned with the end of colonialism.

\section{Guidelines for interreligious dialogue in a postcolonial era}

In this section of the article the author wants to illustrate how a change in attitude between Christians and Muslims can contribute to a theology of religions determining social cohesion in a South African context. From colonialism through apartheid to postcolonialism the historic line is drawn to indicate the differing social contexts and how, in each context, the relationship between religions was determined. 
The end of colonialism brought about a change not only in the structure of society but also a paradigmatic shift in terms of how non-Christian religions were viewed. South Africa struggled for some time to rid itself of the shackles of colonialism. If slavery characterised the largest part of the colonial period, apartheid characterised the immediate postcolonial period in South Africa. The principle of social and religious segregation still applied during the apartheid years, although slavery was abandoned. Denial and exclusion, however, still characterised relationships. A differentiation in terms of members of society was made along racial lines. To belong to the same religion did not grant equal status. A hierarchical structure of society applied: being European meant being privileged and superior; being non-European implied inferiority and being un-privileged. With the dawn of post-colonialism a struggle for independence ensued. This independence was not only for self-governance but a struggle for humanity; being independent from ideologies arranging people along hierarchical strata. Freedom not only meant physical freedom from the shackles of slavery but also free to think, act and believe as one wishes to.

Part of coping with the past is acknowledging the long and winding road history has walked with South African society. Worden (2009:25) indicates how only recently South Africa came to grips with the slavery heritage which was once so much a part of African history. Coming to grips with the apartheid heritage remains an on-going process. Dealing with apartheid is part of the post-colonial struggle and process of healing.

The term post-colonial should be used in a more nuanced way. Sugirtharajah (2006:8) differentiates between 'post-colonial' and 'postcolonial'. The hyphenated form refers to a historical period succeeding the period of colonialism. The un-hyphenated form indicates a dialogical response of the colonised to the ruling knowledge systems introduced by the colonisers and an attempt at restoring the past whilst questioning neo-colonising tendencies. It is clear that 'postcolonial' also refers to a certain methodology of inquiry and response. With 'postcolonial' a particular approach to theology is also implied. This approach has the purpose to investigate and critically analyse all structures of power, dominant systems of thought and ideologies. The outcome is to give recognition to perspectives of marginalised people, cultures and religious entities which once were regarded as being inferior (Bradnick 2011). Sugirtharajah (2006:9) emphasises the unfinished debate about whether postcolonialism should be understood as theory or as criticism. In effect postcolonialism creates a platform for the convergence of opposing views, in terms of multi-ethnicity, multi-religiosity and multi-culturalism (Sugirtharajah 2006:9).

For a long period of time the Western (Eurocentric) perspective was considered the only legitimate perspective. Colonials did not have the opportunity to speak for themselves. The postcolonial (and postcolonial) approach acknowledges the multidimensionality of reality. Sugirtharajah (2006:8) indicates that postcolonialism began during the 1960's coinciding with the colonies' attempts at becoming independent. The South African struggle for independence as a British colony falls in this period. In a post-colonial period all voices have an equal validity and right to be heard. All oppressed and marginalised identities (including nationality, culture, race, gender and sexuality) are now included and recognised. All ideas can now be exchanged and integrated to compile a holistic understanding. The endgoal of post-colonial understanding (Bradnick 2011) is to critique ideologies that support absolutist and totalitarian claims and to provide legitimacy for all possible views, echoing Sugirtharajah (2006:9).

Postcolonialism does not intend to supplant the governing knowledge systems that once ruled supreme but mainly emphasises the right of all to be heard and to criticise. The presence of opposing thoughts resulting from postcolonialism suggests complementarity and does not intend to usurp the dominant position once held by colonial powers. A richer and more varied approach to understanding reality is possible if all perspectives are recognised and acknowledged. In a postmodern paradigm there is no place for one dominant truth, rather a multitude of truths - recognising plurality. In this sense a postcolonial theology of religions needs to take cognisance of the 'other' inhabitants of South Africa and their religions.

Lessons from the past in South Africa provide insight into how social interaction can be structured. About the relationship between Muslims and Christians the apparent contact in the southern tip of Africa was not a favourable one. Being a slave and being a Muslim were equated with one another during the 17th-18th centuries in the Cape Colony. The Muslim perceptions of Christians also contributed to the clouded relationship. Many Christians did not conduct themselves in a moral way in the Cape Colony during the 17th-18th centuries. Muslims looked with disgust upon the immoral actions and words of their colonial owners. Christians did not hold Muslims in high regard. Bear in mind that the Muslim onslaught on Europe only ended in 1684 at the gates of Vienna, thus, presenting Muslims and Christians, in effect, still as enemies as they co-inhabited southern Africa.

Cilliers (2006:110) identifies the following historic obstacles in the conversation between South African Christians and Muslims:

- The status awareness of Christians in the Cape Colony. Slaves were considered to be on the same level as the primitive, un-civilised Khoi-San. Christian-Europeans were considered to be the only educated and civilised people. Compare, in this regard, the entry in the diary of Jan van Riebeeck where he refers to the local inhabitants of the Cape Colony as 'wild and insolent people' (Leipoldt 1936:101-103).

- Christian opportunism: Apparently Christians were willing to baptise slaves in the Cape. When this became an economic liability, baptism was reserved exclusively for Christians - in effect excluding some members of society from social interaction - thus, reserving certain rights and privileges for Christians. 
- The church as facilitator of power: The church determined social interaction and who was in control. Christianity seems to have been the religion of the oppressor in the Cape.

During the post-colonial period, and more so during postapartheid, the South African social context changed. The way in which religions interact and relate to one another also underwent changes. The relationship between religions not only requires an attitude change, as if knowledge of the other brings about treating the other with 'good manners'. What is much rather required is a paradigm shift. The matrix for understanding the religious context should no longer consist of only one religion, such as Christianity. All other religions can no longer be interpreted in terms of how they differ or correspond to Christianity. Postcolonialism requires that the benchmark is no longer based on one religion, side-lining all others, as was the case during the 17th and 18th centuries in South Africa, where Christianity denied and then excluded Islam from social privileges. Postcolonialism requires acknowledging plurality. Several elements can be identified about what the relationship between Muslims and Christians should look like in the post-colonial South African context.

\section{Equal human rights}

With the end of slavery at the Cape Colony a new era in human rights started in South Africa. Slavery ended, but only to be replaced by apartheid - a late remnant of the colonial period. During the period of slavery many slaves were non-Christian as is clear from the above analysis. The social segregation of society was, thus, also along religious lines. This changed very little during the apartheid period. The most privileged group of society under apartheid was European Christians. The unprivileged (non-white) section of society was made up of different religions (although many were also Christians). Again, social segregation was along religious lines although to a lesser degree. Boundaries were set up mainly along racial lines. Religion formed part of the identity of a race. The plurality of reality was denied and ignored. Based on this denial exclusion ensued.

In the post-apartheid era, no social segregation exists formally. The Constitution of South Africa guarantees freedom of religious expression and affiliation. This brought a new dispensation in terms of the equal rights of people from different religions. No social discrimination is tolerated. No social segregation, even along religious lines, is tolerated. The plurality of reality is recognised.

In the post-colonial era religions in South Africa view one another as equals. Kenneth Rose (2013) predicts that pluralism will be the only coherent explanation of religious diversity. With pluralism Rose (2013:9), however, refers to the theory of John Hick, declared in the 1970's, about the theological foundation of the relationship between religions. Pluralism serves as an opposing theory to exclusivism and inclusivism. ${ }^{5}$ Those asking about the relationship Christianity ought to have with other religions must eventually agree with the pluralistic view, according to Rose (2013:2). Acknowledging pluralism is inevitable (Rose 2013:5). One religion can no longer be the only measure of all other religions.

Pluralism recognises the equality and validity of all religions. No religion is inferior to the other. All have knowledge of that which is considered holy. Each religion presents an equal, valid mode of existence. No religion can deny or exclude the other. Pluralism, however, entails the danger of relativism. If all religions matter, it does not matter which religion is followed. This brings about the further danger of possible syncretism - allowing religions to exchange elements to such an extent that the unique identity of a religion disappears (Rose 2013:73).

Postcolonialism does not suggest relativism. It much rather suggests recognition instead of denial, inclusion instead of exclusion.

\section{The place of ethics}

The Cape Colony in the period of the 17th-18th centuries presented several examples about how religions viewed one another: Christian colonisers viewed non-Christians (Muslims included) as equal to uncivilised, primitive natives beyond the reach of help and salvation - inferior to Christianity; denying the presence of transcendence and excluded from society. Muslims on the other hand viewed the Christian colonisers as unethical hypocrites claiming to be pious and righteous but exhibiting unethical behaviour.

In a future theology of religions ethics should play an important role in determining the relationship between religions. Ethics is the most appropriate way to deal with religious plurality (Hedges 2010:255). All religions do not say the same thing or have identical ethical values, but interreligious interaction does include an ethical conversation. Religions do not need to seek a common (global) ethics. Radical openness (Hedges 2010:2) much rather requires a willingness to listen to one another and be open to different interpretations and be willing for a dialogue on ethical matters. Radical openness will ask of Christianity to question its own ethical positions and be critical of itself.

This will require Christians to be honest about their immorality during the colonial period in South Africa and acknowledge and respect that there are different forms of behaviour and interaction. An attitude of openness will prevent Christianity from imposing its ethical structure on society but allow the religious Other room for expression and exercising its ethics. This will prevent a denial and exclusion of the Other.

5.See Gavin D'Costa (1986) for an explanation of the traditional definitions of exclusivism, inclusivism and pluralism as models for understanding the interreligious relations. 


\section{Post-colonial theology of religions}

A theology of religions intends a Christian understanding of the existence and relationship between Christianity and non-Christian religions. Every attempt at a theology of religions must be contextualised. The way in which the Dutch colonisers viewed their relationship with other religions in the colonies was determined by the outcome of the Eighty Years' War that ended in 1648 with the Peace of Münster. The peace agreement brought an end to the Catholic-Protestant War in Europe. The agreement also made provision that each local ruler should determine the religion in the region over which the ruler governs (eius region, eius religio). This resulted in the Dutch colonisers determining, without acknowledging the independence and equality of the non-Christian religions, the status of non-Christian religions as being inferior to Christianity.

In the context of the Cape Colony in the 17th century the principles of plurality and particularity of religions played a significant role. In the Cape Colony it was not only Islam and Christianity to be reckoned with. The local forms of indigenous religions (i.e. Khoi and Traditional African forms of religion) were also part of the milieu. In this plurality of religions, the prominence of Christianity, as determined by colonial regulations, posited Christianity as the dominant religion in the region.

Chidester (1996:xiii) eloquently describes the inter-religious debate by stating that the study of religion is the study of the 'complex relationship between European Enlightenment concepts about the nature of religion and the violent reality experienced by people and cultures all over the world who were conquered and colonised by Europeans'. Colonialism caused religions to be relegated to subordinate status and shifted to the periphery of society. A postcolonial theology of religions wants to address and rectify this situation.

In creating a postcolonial theology of religions, the plurality of religions needs to be acknowledged and accounted for. Paul Hedges (2010), in an attempt to argue a theology of religions, tries to create a balance between plurality and particularity. Although Christianity has grown into a 'radical openness' towards religious 'Others' (Hedges 2010:2) this does, according to Hedges, not mean a subscription to the classical pluralism position as presented by John Hick (compare Hedges 2010:113-115). With the pluralist position Hedges (2010:229) suggests a need to respect the plurality as well as the particularity of all religions. Hick's traditional pluralist position focuses on that which religions have in common, ignoring the differences. Hedges suggests that radical openness should acknowledge the existence of differences. Such radical openness Hedges suggests, is an effort to avoid the impasse of the pluralist-particularist deadlock.

A closed, as opposed to a radical open Christianity, focuses on the set doctrines, beliefs and creeds, excluding all that differs from it and enforces dominance by claiming the sole right to truth (Hedges 2010:230). This closed Christianity is typical of the colonial Euro-centric position that the Dutch colonisers held in the Cape Colony regarding Islam. This position Hedges (2010:230) suggests grew not from a search and application of the truths found in the Gospel but rather from socio-political concerns which formed the Christian identity as the dominant power in society.

For Hedges radical openness entails the possibility of mutual fulfilment of all religions (2010:247). Concerning exactly what is implied with mutual fulfilment, Hedges only mentions that he does not want to present 'easy answers' nor suggest a 'simple recipe' (Hedges 2010:249). He, however, indicates that mutual fulfilment should entail the 'need for religions to overcome the building of barriers and embrace a radical openness to one another' (2010:249). The way in which this plays out is contextually determined. In a post-colonial context such as South Africa it would require that 'the voices that come to us from the margins' are accepted (Hedges 2010:251). Acceptance of the Other implies questioning the Own. In this regard Hedges (2010:252) suggests that Christianity will need seriously to question whether the traditions, denominations and doctrines have not become the idols that Christians worship? Open religiosity cannot deny, ignore or oppress other religions.

In terms of a postcolonial theology of religions, the concept of 'radical openness' (Hedges 2010:2) fits into the understanding of a relationship between Christianity and Islam in South Africa which moves beyond denial and exclusion which characterised it in the 17th-18th centuries.

Jenny Daggers (2013), in an attempt at establishing a theology of religions, indicates the requirement of a new context (i.e. postcolonial) for thinking in a different paradigm about other religions. For a long time the theology of religions - the Christian view of other religions - consisted of 'Eurocentric imperialist attitudes' (Daggers 2013:1). Daggers suggests postcolonial theologies of religious difference (2013:1) to indicate the transition from a monologue by Eurocentric Christians to acknowledging religious plurality. Daggers (2013:2) feels more comfortable within a postcolonial context with a revised particularist theology of religions. She does this in order to pay necessary attention to the particularity of religious traditions and simultaneously respect the integrity of Christianity and other religions. Daggers (2013:2) proposes Christian particularity, grounded in Trinitarian thinking, as being capable of hospitality to postcolonial theologies, recognising interreligious concerns.

Again Daggers (2013:2) does not see the pluralist theology of religions, which she suggests as a continuation of the pluralist theology of John Hick, where other religious traditions are viewed as complementary. She rather sees the task of the revised pluralist model to turn 'theology of religions towards the dynamic process of constructing lived religion within each received tradition'. This new way of 
thinking is necessitated by the religious diversity of the postcolonial world. The context from where other religions are now viewed is no longer a Euro-centric, Christian pivotal perspective, but a disentanglement from this position in order to recognise and acknowledge diversity. This entanglement over centuries saw the understanding of other religions through the lens and in terms of Christian doctrine (Daggers 2013:18), and from this disentanglement is necessary.

With disentanglement Daggers refers to this process of acknowledging the value of local religious expressions in their own context; moving beyond denial and exclusion of other religions.

Chidester identified the problem with colonial theology of religions: Christianity as the dominant religion of the coloniser, interpreting other religions in the colonies in terms of a Christo- and Eurocentric matrix, leads to a denial of the presence of the Holy in other religions and the exclusion of members of such religions from society. Hedges and Daggers try to present a solution about how a theology of religions in a postcolonial era can be constructed. The suggestion of pluralism by Rose might be too extreme as it ignores particularity. Both Hedges and Daggers suggest the acknowledgement of the plurality and diversity of religions in the post-colonial period. Christianity will need to rid itself of an attitude of superiority, open itself (Hedges talks about 'radical openness') to impressions by other religions. Reality needs to be interpreted not only through the Christian lens but disentangled (compare Daggers) from a sole Christian perspective, and view reality through multiple lenses and, thus, recognise diversity.

Christianity in a postcolonial era in South Africa can no longer deny the existence or presence of God in nonChristian religions. Interpreting reality can no longer be restricted or limited to an interpretation based on an exclusive ideology such as Euro-centrism. Other religions must be approached in an unbiased way. There is no longer room for a superior attitude of the knowledgeable coloniser vs primitive colonised. All members of society deserve to be viewed as equals. Those standing on the margins of society must be included - recognising and increasing plurality. Plurality and particularity needs to be respected. In a multi-religious environment such as South Africa acknowledging plurality is not an attempt at equalising all religion. The similarities as well as the differences still require respect.

\section{Conclusion}

As has been stated above every attempt at a theology of religions must be contextualised. The relevant context must be taken into consideration when discussing the relationship between religions. During the colonial period the social condition of slavery determined the view Christians had of Muslims. During the apartheid era social injustice determined the status other religions enjoyed in the eyes of the dominant religion, Christianity. Now during a post-colonial period a new way of thinking about the Other is necessary. Daggers provides the criterion of inclusivity and Hedges the criterion of radical openness. The plurality of reality needs to be recognised and respected. These values contribute to social cohesion. By viewing others as equals and recognising their contribution to the well-being of society and being open to understanding them, society experiences a unity amidst diversity. This may be the best condition for which a pluralistic society may wish.

The early development of society at the Cape Colony, during the 17th-18th centuries, resulted in a multi-cultural and religious pluralistic society. In this diverse environment it is required that religions act as good neighbours and responsible fellow-citizens contributing to the well-being of society. The communality in a South African religious environment lies in the context of people trying to make a living on the same continent facing hardships and challenges together. Religious identity is not only determined by religious differences but also by locality. In this sense postcolonial theology of religions recognises the existence of other religions and accepts their claim to validity and truth.

\section{Acknowledgements Competing interests}

The author declares that he has no financial or personal relationships which may have inappropriately influenced him in writing this article.

\section{References}

Agnos, P., 1978, The Queer Dutchman castaway on ascension in 1725, Green Eagles Press, New York.

Bradnick, D., 2011, 'Postcolonial theology', in The Encyclopedia of Christian Civilization, viewed 4 May 2015, from http://www.onlinelibrary.wiley.com

Chidester, D., 1996, Savage systems: Colonialism and comparative religion in Southern Africa, University Press of Virginia, Charlottesville.

Cilliers, J.L., 2006, 'Christians and Muslims at the Cape of Good Hope: Good hope for whom?', in K.T. August \& C. Sauer (eds.), Christian Muslim encounter in Africa, pp. 102-112, AcadSA Publishing, Johannesburg.

Cummings, W., 2010, The Makassar annals, KITVL Press, Leiden.

D'Costa, G., 1986, Theology and religious pluralism, Blackwell, Oxford.

Daggers, J., 2013, Postcolonial theology of religions: Particularity and pluralism in World Christianity, Routledge, London.

Dangor, S.E., 1981, 'A critical biography of Shaykh Yusuf', MA thesis, Department of Islamic Studies, University of Durban-Westville, Durban.

Dangor, S.E., 1982, Shayk Yusuf, IQRA, Research Committee, Mobeni.

Du Plessis, J., 1965, A history of Christian missions in South Africa, Struik, Cape Town.

Hedges, P., 2010, Controversies in interreligious dialogue and the theology of religions, SCM Press, London.

Leipoldt, C.L., 1936, Jan van Riebeeck: Biographical study, Longmans, Green and Co., London.

Ligtvoet, A., 1880, Transcriptie van het dagboek der vorsten van Gowa en Tello met vertaling en aantekeningen, $\mathrm{S}^{\prime}$ Gravenhage.

Rose, K., 2013, Pluralism: The future of religion, Bloomsbury, New York.

Shell, R.C.-H., 2000, 'Islam in Southern Africa, 1652-1998', in N. Levtzion \& R.L. Pouwels (eds.), The history of Islam in Africa, pp. 327-348, Ohio University Press, Ohio.

Spilhaus, W., 1949, The first South Africans, Juta, Cape Town.

Sugirtharajah, R.S., 2006, 'Charting the aftermath: A review of postcolonial criticism', in R.S. Sugirtharajah (ed.), The postcolonial biblical reader, pp. 7-32, Blackwell Publishing, Cornwall. http://dx.doi.org/10.1002/9780470775080 
Van Selms, A., \& Yusuf, S., 1968, in W.J. De Kock (ed.), Dictionary of South African Biography I, pp. 893-4, Cape Town.

Villa-Vicencio, C. \& Grassow, P., 2005, 'Christianity and the colonization of South Africa, 1652-1870', in The social history of Christianity in South Africa 1487-1994, Research Institute on Christianity and Society in Africa, University of Cape Town, Cape Town, viewed 27 May 2015, from http://web.uct.ac.za
Worden, N., 2009, 'The changing politics of slave heritage in the Western Cape, South Africa', Journal of African History 50, 23-40. http://dx.doi.org/10.1017/ S0021853709004204

Yusuf, S., 1990, Zubdat al-Asrār: The essence of secrets, transl. S.E. Dangor, Islamic Studies Publication Series no. 3, Centre for Research in Islamic Studies, University of Durban-Westville, Durban. 